\title{
PENERAPAN TQM DALAM PENDIDIKAN AKHLAK
}

\author{
Novan Ardy Wiyani \\ M. Najib \\ Sholichin \\ STAIN Purwokerto \\ Jl. Jend. A. Yani No. 40 A Purwokerto \\ Email : fenomenajiwa@Gmail.com
}

\section{ABSTRAK}

Penelitian ini bertujuan mengetahui langkah-langkah penerapan Total Quality Management (TQM) di Sekolah Dasar (SD) Al Irsyad Al Islamiyyah 02 Purwokerto dalam rangka membentuk karakter peserta didik. Penelitian ini bersifat deskriptif-kualitatif. Teknik pengumpulan data yang digunakan adalah wawancara, observasi dan dokumentasi. Data dikumpulkan melalui triangulasi dan dianalisis secara induktif, yaitu melalui tahapan pencatatan, pengorganisasian dan pengkodean data. Hasil penelitian menunjukkan bahwa ada lima langkah yang dilakukan SD Al Irsyad Al Islamiyyah 02 Purwokerto dalam mengimplementasikan TQM untuk membentuk karakter peserta didik, yaitu; 1) melakukan perbaikan karakter peserta didik secara terus menerus; 2) menetapkan jaminan mutu karakter peserta didik; 3) mengubah budaya sekolah guna membentuk karakter peserta didik; 4) melakukan perubahan organisasi sekolah dalam rangka membentuk karakter peserta didik. 5) menjalin kerjasama dengan wali peserta didik dalam membentuk karakter peserta didik.

Kata Kunci: Total Quality Management, Program Pendidikan Akhlak, Karakter

\section{ABSTRACT}

This study is proposed to know the steps in implementing Total Quality Management (TQM) to form the character of students in elementary Al Irshad Al Islamiyyah 02 Purwokerto. The research used cualitative-descriptive approach. Data collection techniques used in this research were interviews, observation and documentation. Data were collected through triangulation and analyzed by using inductive data analysis techniques following three steps: namely note taking, organizing and coding. The research result shows that there are five steps taken in implementing TQM to form the character of students in elementary Al Irshad Al Islamiyyah 02 Purwokerto. First, Improving student's character continuously. Second, establishing quality assurance for the student's character. Third, changing the culture of schools to shape the character of the students. Fourth, changing school organization to form the character of students. Fifth, establishing the network with guardians of students in shaping the character of students.

Keywords: Total Quality Management, Akblak Educational Program, Character 


\section{PENDAHULUAN}

Hasil penelitian Sa'dun Akbar sepanjang 2004-2009 di beberapa sekolah dasar (SD) menunjukkan bahwa: Pertama, pada umumnya rasa memiliki dan rasa tanggung jawab peserta didik terhadap fasilitas sekolah sangat rendah. Ini ditemukan di sebuah SD di Riau dan Kalimantan Timur. Ada mesin AC yang dimasuki uang logam, paku dan benda-benda lainnya. Ada pula yang mencoratcoret bangku sekolah dan kamar mandi, hingga membuang sampah sembarangan. Kedua, sopan santun, tanggung jawab dan rasa memiliki peserta didik terhadap barang miliknya sendiri juga sangat rendah. Banyak barang-barang milik peserta didik tertinggal di sekolah tetapi tidak mereka cari. Suatu ketika dijumpai seorang peserta didik sedang menarik tas sekolahnya yang beroda, tampak tasnya terguling sehingga kedua rodanya tidak menyentuh tanah tetapi ia tetap saja menyeretnya. Kemudian seorang guru berkata, "Tas Adik kan masih baru dan bagus, kalau diseret begini kan rusak?". Dengan spontan si peserta didik menjawab, "Emangnya Gue pikirin!". Lalu ketika peserta didik dari SD tertentu di Kalimantan Timur berwisata di Batu Malang, ditemukan banyak pakaian dalam dan pakaian kotor ditinggal begitu saja di kamar-kamar mandi di hotel Agro Kusuma Batu. Ketiga, di sebuah SD di Riau terjadi pergaulan yang kurang setara antara peserta didik yang orang tuanya sebagai pekerja kelas atas (yang lebih dikenal sebagai anak papa) dengan peserta didik yang orang tuanya sebagai pekerja kelas bawah (yang lebih dikenal dengan anak pipa). Mereka tidak bisa membaur dan saling bergaul satu sama lain. Keempat, dari 75 guru SD di Jawa Timur yang mengisi angket semi terbuka mengungkapkan bahwa banyak terjadi perilaku yang tidak diharapkan seperti perilaku terlambat masuk kelas, tidak mengerjakan PR, berbicara keras-keras, mudah marah dan berkelahi, premanisme, mengolok-olok teman, membantu teman berkelahi, corat-coret bangku sekolah, melarang adik kelasnya melintas di depannya dan kebiasaan mencontek (Wiyani, 2012: 11).

Pendidikan nasional Indonesia dianggap oleh para pengamat maupun masyarakat luas pada dasarnya belum mampu mencerdaskan kehidupan bangsa dalam arti melahirkan anak-anak bangsa yang berakhlak mulia. Kegelisahan masyarakat tersebut direspons oleh SD Al Irsyad Al Islamiyyah 02 Purwokerto. SD tersebut memadukan Total Quality Management (TQM) dengan Program Pendidikan Akhlak (PPA).

TQM adalah suatu metode/model/pendekatan yang digunakan oleh suatu perusahaan untuk memaksimalkan daya saing organisasi melalui perbaikan terusmenerus atas produk, jasa, manusia, proses dan lingkungannya (Tjiptono dan Anastasia Diana, 2009: 4). Meskipun TQM ini lazimnya diimplementasikan di perusahaan namun kini lembaga pendidikan juga sudah mulai menerapkannya, seperti di SD Al Irsyad Al Islamiyyah 02 Purwokerto. Jika produk dari perusahaan adalah umumnya barang yang berkualitas, maka produk dari penyelenggaraan pendidikan di SD Al Irsyad Islamiyyah 02 Purwokerto adalah peserta didik yang berkarakter/berakhlak mulia. Penelitian ini bertujuan 
menggambarkan langkah-langkah dalam mengimplementasikan TQM untuk membentuk karakter peserta didik di SD Al Irsyad Al Islamiyyah 02 Purwokerto yang dapat digunakan sebagai acuan bagi SD lainnya.

Penelitian ini merupakan penelitian lapangan (field study) dan bersifat deskriptif-kualitatif. Berdasarkan sumbernya, data dikumpulkan dari person, place, dan paper. Teknik pengumpulan data yang digunakan yaitu; 1) wawancara mendalam. Teknik ini digunakan untuk melukiskan kehidupan warga sekolah di SD Al Irsyad Al Islamiyyah 02 Purwokerto. Pertanyaan-pertanyaan yang disampaikan kepada informan berhubungan dengan implementasi TQM dalam membentuk karakter peserta didik melalui program pendidikan akhlak (PPA). Informan dalam penelitian ini adalah kepala sekolah, wakil kepala sekolah, guru kelas, guru mata pelajaran dan staf serta peserta didik; 2) observasi partisipan atau pengamatan terlibat. Melalui teknik ini peneliti mengamati gejala-gejala yang ada dalam kehidupan sehari-hari guru dan peserta didik di SD Al Irsyad Al Islamiyyah 02 Purwokerto disertai dengan dialog, mendengarkan, merasakan dan dalam batas-batas tertentu mengikuti berbagai kegiatan yang dilakukan oleh guru dan peserta didik dalam kegiatan PPA. Dialog dilakukan secara spontan dan apa adanya namun terarah kepada fokus masalah (Patilima, 2011: 87). 3) teknik dokumentasi. Teknik ini digunakan agar data-data penelitian dalam bentuk tulisan dan gambar-gambar yang berhubungan dengan pelaksanaan kegiatan implementasi TQM untuk membentuk akhlaq peserta didik melalui program pendidikan PPA dapat dimaknai secara mendalam dan akurat. Seluruh data kemudian dikumpulkan secara triangulasi berdasarkan sumber dan teknik, yakni dengan menggabungkan teknik wawancara, observasi dan dokumentasi secara simultan sehingga diperoleh data yang lebih natural dan akurat (Afifudin dan Saebani, 2009 :23). Data yang telah terkumpul kemudian dianalisis oleh penulis dengan menggunakan teknik analisis data secara induktif (Moleong, 2011: 10) yaitu melakukan pencatatan, pengorganisasian data dan pengkodean. Dalam pencatatan, hasil wawancara, observasi dan analisis terhadap dokumen seteliti mungkin dicatat. Dalam pengorganisasian, data dikelompokan berdasarkan subjek/aspek/sub variabel penelitian. Dalam pengkodean dilakukan pembacaan sekaligus pengembangan deskripsi hasil bacaan secara teliti (Moleong, 2011: 296).

\section{PEMBAHASAN}

Total Quality Management (TQM) di Indonesia sering diistilahkan dengan manajemen mutu terpadu. Kata 'manajemen' berasal dari bahasa Inggris, yaitu management yang berasal dari kata to manage, artinya mengurusi dan mengelola. Manajemen juga berasal dari bahasa Perancis kuno, yaitu menagement yang berarti seni melaksanakan dan mengatur. Itulah yang menjadikan manajemen sering diartikan sebagai ilmu, kiat dan profesi. Luther Gulick mengungkapkan bahwa manajemen dikatakan sebagai ilmu karena manajemen dipandang sebagai suatu bidang pengetahuan yang secara sistematik berusaha memahami mengapa dan 
bagaimana orang bekerja sama. Follet mengatakan manajemen sebagai kiat dikarenakan manajemen mencapai sasaran melalui berbagai cara dengan mengatur orang lain dalam menjalankan tugas. Manajemen juga dipandang sebagai profesi dikarenakan manajemen dilandasi oleh keahlian khusus untuk mencapai suatu prestasi manajer (Wiyani, 2012: 38).

Sayyid Mahmud al-Hawariy dalam bukunya "al-Idaroh al-Ushul wal Ushushil Ilmiyah" mengartikan manajemen sebagai suatu sikap seseorang maupun sekelompok orang untuk mengetahui ke mana arah yang dituju, kesukaran apa yang harus dihindari, kekuatan apa yang harus dijalankan, dan bagaimana mengemudikan kapal serta anggotanya dengan sebaik-baiknya tanpa adanya pemborosan waktu dalam proses mengerjakannya (Sulistyorini, 2009: 11). Syafaruddin dan Irwan Nasution menegaskan bahwa manajemen adalah kekuatan utama dalam organisasi dalam mengoordinir berbagai kegiatan dan bagian-bagian (sub sistem) yang berhubungan dengan lingkungan organisasi (Syafaruddin dan Irwan Nasution, 2005: 70). Jadi, dapat dikatakan bahwa manajemen merupakan kegiatan mengelola suatu organisasi untuk mencapai tujuan yang telah ditetapkan dengan memperhatikan prinsip dan metode tertentu untuk mencapai tujuan-tujuan tertentu.

Quality diterjemahkan ke dalam Bahasa Indonesia menjadi 'kualitas' atau 'mutu'. Edward Sallis (2010: 33) mengungkapkan bahwa mutu berhubungan dengan suatu hal yang membedakan antara yang baik dan yang sebaliknya. Sallis mengungkapkan bahwa mutu merupakan suatu prinsip yang dapat membantu suatu institusi untuk merencanakan perubahan dan mengatur agenda dalam menghadapi tekanan-tekanan eksternal yang berlebihan. Vincent Gaspersz (2008: 4) membagi pengertian mutu menjadi dua yaitu; 1) gambaran karakteristik langsung dari suatu produk, seperti unjuk kerja (performance), keandalan (reliability), mudah dalam penggunaan (easy to use), dan indah (esthetics). Mutu dalam arti yang pertama ini bersifat konvensional; 2) mutu dalam arti strategik. Dalam arti ini, mutu adalah segala sesuatu yang mampu memenuhi keinginan, kebutuhan dan kepuasan pelanggan (meeting the needs of customers). Jadi mutu dapat diartikan sebagai kebanggaan dan kepuasan pelanggan terhadap suatu produk baik berupa barang maupun jasa yang dihasilkan oleh suatu organisasi. Kepuasan tersebut berhubungan dengan pemenuhan keinginan dan kebutuhan pelanggan serta rasa bangga pada diri pelanggan terhadap produk organisasi tersebut. Dari penjelasan tersebut dapat dimaknai bahwa Total Quality Management (TQM) atau manajemen mutu terpadu adalah metode yang digunakan dalam mengelola sumber daya manusia pada suatu organisasi secara terus-menerus untuk mencapai tujuantujuan yang telah ditetapkan.

Sallis (2010: 43) mengungkapkan bahwa implementasi TQM di bidang pendidikan masih tergolong baru. Menurutnya pada tahun 1980-an hanya ada sedikit literatur yang memuat referensi tentang implementasi TQM di bidang pendidikan. Pada tahun itu beberapa universitas di Amerika sudah mengimplementasikan TQM sebagai upaya reorganisasi terhadap praktik kerja 
stakeholders pendidikan. Setelah Amerika, Inggris menyusul mengimplementasikannya. Baru pada tahun 1990-an di kedua negara tersebut TQM betul-betul diimplementasikan secara luas bukan hanya di perguruan tinggi tetapi juga di sekolah-sekolah.

Jerome S. Arcaro (2007: 10) mengungkapkan bahwa ketika TQM diimplementasikan secara tepat, ia dapat menjadi metode yang dapat membantu para profesional pendidikan dalam menjawab tantangan lingkungan masa kini. Implementasi TQM dapat mengurangi rasa takut sekaligus meningkatkan kepercayaan diri lembaga terhadap penyelenggaraan pendidikan di lingkungan sekolahnya. Selain sebagai metode, menurutnya TQM juga dapat diimplementasikan sebagai media untuk membangun aliansi antara dunia pendidikan, bisnis dan pemerintahan. Aliansi tersebut dapat memastikan bahwa para profesional sekolah atau pemerintah wilayah dapat memberikan sumber daya yang dibutuhkan untuk mengembangkan program-program pendidikan. TQM dapat memberikan fokus pada pendidikan dan masyarakat/pelanggan. TQM membentuk infrastruktur yang fleksibel yang mampu memberikan respons yang cepat terhadap perubahan dan tuntutan masyarakat. TQM juga dapat membantu sekolah menyesuaikan diri dengan keterbatasan dana dan waktu serta memudahkan sekolah dalam mengelola perubahan.

Sekolah sebagai sebuah lembaga pendidikan dapat dikategorikan sebagai lembaga industri mulia (noble industry) karena mengemban misi ganda yaitu profit sekaligus sosial. Misi profit yaitu untuk mencapai keuntungan. Ini dapat dicapai saat efisiensi dan keefektifan dana bisa terwujud sehingga pemasukan (income) lebih besar dari pada biaya operasional. Sedangkan misi sosial bertujuan mewariskan dan menginternalisasikan nilai-nilai luhur. Misi sosial sekolah dapat dicapai secara maksimal ketika sekolah memiliki buman-capital dan social-capital yang memadai dengan tingkat keefektifan serta efisiensi yang tinggi dalam bekerja. Itulah sebabnya me-manage sekolah dengan mengimplementasikan TQM dipandang sebagai suatu pilihan yang tepat.

Edward Sallis (2010: 69) mengungkapkan bahwa tujuan dari diimplementasikannya TQM di sekolah adalah untuk mengubah pihak-pihak yang mengoperasikan sekolah menjadi sebuah tim yang ikhlas, tanpa konflik dan kompetitif secara internal untuk meraih suatu tujuan tunggal, yaitu memuaskan pelanggan. Menurut Tony Bush dan Marianne Coleman (2010: 192), TQM yang diimplementasikan di sekolah memberikan tiga manfaat, yaitu; 1) dapat menggerakkan nilai, moral, karakter dan akhlak yang jelas berdasarkan suatu keyakian bahwa dalam mengimplementasikan TQM semua pihak harus bekerja dengan maksimal baik di awal, di tengah dan hingga di akhir; 2) dapat memuaskan keinginan maupun kebutuhan orang tua peserta didik. Orang tua peserta didik menyekolahkan anaknya didasarkan pada sejumlah kebutuhan dan harapan tertentu. Implementasi TQM menjadikan pihak sekolah mengetahui kebutuhan dan harapan tersebut serta menjadikan pihak sekolah fokus dan mampu untuk memenuhi kebutuhan dan harapan para orang tua peserta didik. 
Itulah sebab tujuan akhir dari TQM adalah kepuasan para pelanggan. Pelanggan sendiri adalah wasit terhadap mutu dan sekolah tidak akan mampu bertahan tanpa mereka; 3) dapat mencegah terjadinya sesuatu yang tidak diinginkan atau sesuatu yang buruk. Hal ini sangat mungkin sekali dicapai karena implementasi TQM merupakan perluasan dan pengembangan diri dari jaminan mutu (quality assurance). Jaminan mutu adalah sebuah cara memproduksi produk yang bebas dari catat dan kesalahan (zero defects).

Dalam implementasi TQM di sekolah terdapat langkah-langkah yang sistematis yang dikerjakan secara teratur dan terus-menerus. Langkah-langkah tersebut menurut Sallis (2010: 8-11) yaitu;

1. Melakukan perbaikan secara terus-menerus. Konsep ini mengandung pengertian bahwa pihak pengelola sekolah senantiasa melakukan berbagai perbaikan dan peningkatan secara terus-menerus untuk menjamin semua komponen penyelenggara pendidikan mengarah pada visi, misi dan tujuan sekolah. Untuk itu kepala sekolah memberikan kepercayaan kepada para guru dan staf dalam bekerja mewujudkan visi, misi dan tujuan sekolah tersebut;

2. Menentukan standar mutu. Konsep ini disebut juga dengan jaminan mutu (quality assurance). Jaminan mutu merupakan salah satu usaha untuk menyelenggarakan pendidikan yang menerapkan prinsip penggunaan sumber daya secara efisien. Paham ini digunakan untuk menetapkan standar-standar mutu dari semua komponen yang bekerja dalam proses produksi atau transformasi lulusan sekolah. Jaminan mutu ini dapat berupa kepemilikan atau kemampuan dasar pada masing-masing bidang pendidikan dan sesuai dengan jenjang pendidikan yang ditempuh;

3. Melakukan perubahan kultur. Konsep ini bertujuan untuk membentuk budaya sekolah yang menghargai mutu dan menjadikan mutu sebagai orientasi seluruh stakeholders sekolah. Jika TQM diimplementasikan di sekolah, maka pihak pimpinan harus berusaha membangun kesadaran para anggotanya, mulai dari pemimpin sendiri, staf, guru, peserta didik, orang tua peserta didik, dan yayasan akan pentingnya mempertahankan dan meningkatkan mutu pendidikan, baik mutu hasil maupun mutu proses;

4. Mengubah organisasi. Perubahan organisasi ini bukan berarti perubahan wadah organisasi tetapi sistem atau struktur organisasi yang melambangkan hubungan-hubungan kerja dan kepengawasan dalam organisasi. Perubahan ini menyangkut perubahan kewenangan serta tugas-tugas dan tanggung jawab. Misalnya dalam kerangka manajemen berbasis sekolah, struktur organisasi dapat berubah terbalik dibanding dengan struktur konvensional. Jika dalam struktur konvensional berturut-turut dari atas ke bawah: kepala sekolah, wakil kepala sekolah, guru, dan staf, sedangkan dalam struktur baru yaitu dalam 
struktur organisasi layanan keadaannya berbalik dari atas ke bawah berturut-turut: peserta didik, guru dan staf, wakil kepala sekolah, dan kepala sekolah. Jika visi dan misi serta tujuan sekolah sudah berubah atau mengalami perkembangan, maka sangat dimungkinkan terjadinya perubahan organisasi;

5. Mempertahankan hubungan baik dengan pelanggan. Sekolah menghendaki kepuasan pelanggan, maka sekolah mempertahankan hubungan baik dengan pelanggan dan itu menjadi sesuatu yang sangat diperlukan. Hubungan baik tersebut dapat terwujud jika sekolah mau dan mampu menggandeng orang tua peserta didik dan masyarakat sekitar sebagai mitranya dalam mensukseskan berbagai kegiatan pendidikan di sekolah

\section{Pendidikan Karakter dalam Perspektif Islam}

Pendidikan secara bahasa dapat diartikan sebagai proses pengubahan sikap dan tata laku seseorang atau sekelompok orang dalam usaha mendewasakan manusia melalui upaya pengajaran, pelatihan dan pembimbingan. Pendidikan juga dapat berarti proses, cara dan perbuatan mendidik (Alwi, 2002: 263). Sedangkan secara istilah pendidikan dapat diartikan sebagai usaha sadar dan terencana untuk mewujudkan suasana belajar dan proses pembelajaran agar peserta didik secara aktif mengembangkan potensi dirinya untuk memiliki kekuatan spiritual keagamaan, pengendalian diri, kepribadian, kecerdasan, akhlak mulia, serta keterampilan yang diperlukan oleh dirinya, masyarakat, bangsa dan negara (Arifin, 2003: 34). Dari pengertian pendidikan tersebut, maka setidaknya pendidikan memiliki dua fungsi yaitu; pertama, fungsi progresif dan kedua fungsi konservatif. Dalam fungsi progresif, aktivitas pendidikan dapat memberikan bekal dan pengembangan ilmu pengetahuan, penanaman nilai-nilai, penguasaan keterampilan untuk mengantisipasi masa depan agar generasi penerus bangsa mempunyai kemampuan dan kesiapan untuk menghadapi tantangan di masa kini dan masa mendatang. Dalam fungsi konservatif, aktivitas pendidikan berupaya mewariskan dan mempertahankan cita-cita dan budaya suatu masyarakat kepada generasi penerus (Asifudin, 2010: 12).

Jika kedua fungsi pendidikan tersebut dihubungkan dengan eksistensi dan hakikat kehidupan manusia, maka pada dasarnya pendidikan diarahkan untuk membentuk kepribadian manusia, yaitu mengembangkan manusia sebagai makhluk individu, sosial, susila beragama (Tahroni, 2009: 8). Jadi dapat dikatakan bahwa tujuan utama diselenggarakannya pendidikan bukan untuk menciptakan peserta didik yang semata-mata cerdas secara intelektual tetapi juga ditujukan untuk membangun kepribadian peserta didik.

Kepribadian merupakan organisasi faktor-faktor biologis, psikologis dan sosiologis yang mendasari perilaku individu. Kepribadian bagi peserta didik mencangkup kebiasaan-kebiasaan, sikap dan sifat lain yang khas dimiliki oleh seorang peserta didik yang berkembang jika ia berhubungan dengan orang lain. 
Berarti, kepribadian di antara seorang peserta didik dengan peserta didik yang lain tidak sama. Masing-masing memiliki kekhasan, oleh karenanya kepribadian sering diistilahkan dengan kata "karakter". Jadi karakter adalah ciri khas yang dimiliki oleh individu. Ciri khas tersebut asli dan mengakar pada kepribadian individu serta merupakan ruh/substansi penggerak seseorang dalam bertindak, bersikap dan merespons sesuatu sesuai dengan norma-norma yang berlaku. Seseorang dikatakan berkarakter (memiliki karakter) apabila ia telah berhasil menyerap nilai dan keyakinan yang dikehendaki masyarakat serta digunakan sebagai acuan dalam menjalani hidupnya. Dari deskripsi tersebut maka pendidikan karakter dapat diartikan sebagai usaha sadar dan terencana untuk membentuk, mengarahkan dan membimbing perilaku peserta didik dalam kehidupan sehari-hari yang sesuai dengan norma-norma yang berlaku di masyarakat. Dalam perspektif Islam, pendidikan karakter dapat didefinisikan sebagai upaya sadar dan terencana untuk membentuk, mengarahkan dan membimbing akhlak peserta didik dalam kehidupan sehari-hari yang sesuai dengan ajaran Islam yang bersumber dari al-Qur'an, Hadist dan ijtihad para ulama.

Istilah lain dari pendidikan karakter dalam perspektif Islam adalah pendidikan akhlak. Akhlak berasal dari kata khalaqa dengan akar kata khuluqan (bahasa Arab) yang berarti perangai, tabi'at, adat atau dari kata khalqun (bahasa Arab) yang berarti kejadian, buatan atau ciptaan. Jadi, secara etimologis akhlak berarti perangai, adat, tabi'at atau sistem perilaku yang diperbuat seseorang. Dengan demikian akhlak bisa baik dan bisa juga buruk. Akhlak yang baik disebut akhlak mahmudah dan akhlak yang buruk disebut akhlak madzmumah. Dalam konteks pendidikan nasional Indonesia, kata akhlak selalu berkonotasi positif. Oleh karena itu, orang yang baik sering disebut sebagai orang yang berakhlak dan orang yang berbuat tidak baik seringkali disebut orang yang tidak berakhlak (Nurdin, dkk., 2001: 205). Dalam konteks pendidikan, penanaman akhlak dikonstruksi menjadi metode pembelajaran akhlak Metode ini umumnya dikonstruksi dari pengertian umum pembelajaran, berdasarkan UUSPN No. 12 Tahun 2003 yaitu sebagai proses interaksi peserta didik dengan pendidik dan sumber belajar pada suatu lingkungan belajar. Pembelajaran merupakan proses belajar yang dibangun oleh guru untuk mengembankan kreativitas berfikir yang dapat meningkatkan kemampuan mengonstruksi pengetahuan baru sebagai upaya meningkatkan penguasaan yang baik terhadap materi pelajaran (UUSPN No. 12 Tahun 2003 Darwis, 2012: 387). Dengan demikian dapat dikatakan bahwa akhlak merupakan sistem perilaku yang harus dibuat/dibangun. Berhubungan dengan hal itu, maka diperlukan upaya pembentukan akhlak melalui penyelenggaraan pendidikan, yang dikenal dengan istilah pendidikan akhlak atau pendidikan karakter.

Penjelasan di atas menunjukkan bahwa pendidikan karakter mempunyai orientasi yang sama dengan pendidikan akhlak, yaitu membentuk karakter yang kuat dan pribadi mulia. Bedanya, pendidikan akhlak terkesan ke-Timuran dan 
Islami, sedangkan pendidikan karakter terkesan Barat dan sekuler. Singkatnya, pendidikan akhlak memiliki makna yang secara khusus menunjukkan suatu upaya pembentukan karakter yang dilakukan oleh umat Islam. Sedangkan pendidikan karakter memiliki makna yang lebih umum (general), yakni pembentukan karakter yang dilakukan oleh semua umat, baik umat Islam maupun umat beragama lainnya. Perbedaan tersebut bukan menjadi sebuah alasan yang harus dipertentangkan. Thomas Lickona sebagai Bapak Pendidikan Karakter di Amerika justru mengisyaratkan ada hubungan yang erat antara karakter dengan spiritualitas (Zubaedi, 2012: 65).

\section{Implementasi TQM di SD Al Irsyad Al Islamiyyah 02 Purwokerto}

Ada lima upaya yang dilakukan oleh SD Al Irsyad Al Islamiyyah 02 Purwokerto dalam mengimplementasikan TQM untuk membentuk karakter peserta didik yaitu; 1) melakukan perbaikan karakter peserta didik secara terusmenerus; 2) menetapkan jaminan mutu karakter peserta didik; 3) merubah budaya sekolah untuk membentuk karakter peserta didik; 4) melakukan perubahan organisasi sekolah untuk membentuk karakter peserta didik dan 5) menjalin kerjasama dengan wali peserta didik dalam membentuk karakter peserta didik.

1. Perbaikan karakter peserta didik secara terus-menerus. Perbaikan tersebut ditempuh dengan dua upaya, yaitu;

a. Memfokuskan Visi SD Al Irsyad Al Islamiyyah 02 Purwokerto pada pembentukan karakter peserta didik.Visi SD Al Irsyad Al Islamiyyah 02 Purwokerto adalah "Menjadi sekolah Islam unggulan di Jawa Tengah melalui penerapan manajemen mutu untuk meluluskan murid yang berakhlak mulia, berprestasi akademik tinggi dan berwawasan global". Dari visi tersebut diperoleh temuan bahwa SD Al Irsyad Al Islamiyyah 02 Purwokerto telah mengimplementasikan model TQM dengan adanya rangkaian kata "penerapan manajemen mutu". Implementasi TQM tersebut lebih memfokuskan pada pembentukan karakter peserta didik dengan menempatkan rangkaian kalimat/frasa "meluluskan murid yang berakhlak mulia" di awal redaksional tentang visi, kemudian baru diikuti dengan rangkaian kalimat "berprestasi akademik tinggi dan berwawasan global". Visi sekolah dirumuskan melalui musyawarah yang dilakukan oleh para guru, wali peserta didik, komite sekolah dan LPP/Yayasan Al Irsyad Al Islamiyah Purwokerto. Perumusan visi sekolah dengan melibatkan seluruh stakeholders sekolah diharapkan dapat memunculkan pandangan dan komitmen yang sama dan kuat dalam menyelenggarakan kegiatan pendidikan.

b. Membuat suatu program untuk membentuk karakter peserta didik. Selain diminta untuk menyampaikan ide-idenya dalam perumusan visi sekolah, guru juga diminta untuk menyampaikan gagasan- 
gagasannya yang berhubungan dengan visi untuk mencapai visi sekolah dan penyelenggaraan program sekolah khususnya untuk membentuk karakter peserta didik. Program tersebut dijadikan semacam inovasi yang ditujukan untuk membentuk karakter peserta didik. Program tersebut, di SD Al Irsyad Al Islamiyyah 02 Purwokerto menjadi program unggulan dan diimplementasikan melalui TQM. Program implementasi TQM untuk membentuk karakter peserta didik di SD Al Irsyad Al Islamiyyah 02 Purwokerto dinamai dengan istilah Program Pendidikan Akhlaq (PPA). Program ini merupakan program pencapai jaminan mutu atau Quality Assurance (QA) sebagai Tool skill untuk mencapai prestasi akademik. PPA berada di seluruh kegiatan, baik kegiatan pembelajaran mata pelajaran, kegiatan ekstra kurikuler dan kegiatan lainnya seperti pagi ceria, pembiasaan makan tertib dan shalat, bahkan PPA mencakup juga kegiatan tertentu di rumah. Dengan demikian PPA dilaksanakan secara terintegrasi dengan kegiatan pembelajaran pada beberapa mata pelajaran, kegiatan ekstrakurikuler serta berbagai kegiatan pembiasaan, baik kegiatan pembiasaan di sekolah maupun kegiatan pembiasaan di rumah. Kegiatan pembiasaan tersebut dijadikan sebagai kegiatan utama dalam pelaksanaan PPA.

2. Menetapkan jaminan mutu karakter peserta didik. Dalam konteks ini kepatuhan peserta didik merupakan karakter utama yang hendak dibentuk dalam kegiatan PPA di SD Al Irsyad Al Islamiyyah 2 Purwokerto selain karakter-karakter yang lainnya, seperti hormat dan patuh kepada guru dan orang tua, rajin shalat dan mengaji, kejujuran serta kesopanan. Kepemilikan karakter-karakter tersebut kemudian menjadi spesifikasi lulusan peserta didik. Untuk memenuhi spesifikasi lulusan tersebut disusun jaminan mutu (quality assurance) karakter peserta didik. Jaminan Mutu lulusan SD Al Irsyad Al Islamiyyah 02 Purwokerto terdiri atas objek, aspek dan indikator utama. Objek PPA terdiri dari atas unsur, yaitu akhlak kepada Allah SWT, akhlak kepada makhluk (orang lain dan lingkungan) serta akhlak kepada diri sendiri. Akhlak kepada diri sendiri diurai menjadi tiga sub bagian yaitu soft skill, tools skill dan akademis. Setiap bagian memiliki beberapa aspek, totalnya ada 23 aspek. Jaminan mutu tersebut dibuat oleh tim yang terdiri atas kepala sekolah, wali kelas (waka level) dan guru yang dibentuk oleh kepala sekolah sebelum awal tahun pelajaran baru dimulai. Jaminan mutu tersebut kemudian menjadi standar mutu yang hendak dicapai dalam kegiatan PPA melalui berbagai strategi pembiasaan yang sesuai dengan kebiasaan-kebiasaan yang lazim dilakukan oleh peserta didik. Untuk mengukur pencapaian standar mutu PPA dilakukan evaluasi PPA. Prosedur evaluasi PPA dirumuskan berdasarkan jaminan mutu PPA dan standar mutu PPA yang harus dikuasai oleh peserta didik. 
Prosedur evaluasi tersebut dirumuskan oleh kepala sekolah dan LPP/yayasan bagian kesiswaan. Sedangkan guru hanya diminta untuk memberikan masukan terhadap prosedur evaluasi PPA. Jalannya evaluasi PPA dilaksanakan oleh masing-masing wali kelas dan oleh guru yang ditunjuk serta oleh orang tua peserta didik sendiri selama satu bulan sekali.

3. Merubah budaya sekolah untuk membentuk karakter peserta didik. Perubahan budaya sekolah untuk membentuk karakter peserta didik di SD Al Irsyad Al Islamiyyah 02 Purwokerto dilakukan melalui lima upaya, yaitu:

a. Pembuatan dan penerapan tata tertib sekolah. Tata tertib yang diberlakukan di SD Al Irsyad Al Islamiyyah 02 Purwokerto sebenarnya bukan hanya sekedar sebuah peraturan yang harus ditaati tetapi lebih dari itu tata tertib tersebut merupakan tool (alat) yang digunakan oleh tim PPA untuk menciptakan budaya sekolah yang mendukung pembentukan karakter peserta didik.

b. Pelaksanaan berbagai kegiatan pembiasaan pada PPA. Prinsip utama yang dijadikan sebagai pegangan dalam pelaksanaan PPA adalah "Pembiasaan sejak dini harus dilakukan untuk peserta didik kami”. Dalam PPA peserta didik diberi berbagai pembiasaan yang akan membuat peserta didik terbiasa melakukan kegiatan yang positif, seperti jadi terbiasa melakukan sholat, membaca al-Qur'an, makan sambil duduk, senyum dan salam, menghormati teman, serta berjabat tangan.

c. Melakukan pengkondisian untuk mendukung kegiatan pembiasaan pada PPA. Kegiatan pengkondisian dilakukan melalui pengadaan berbagai fasilitas penunjang untuk mendukung pelaksanaan kegiatan PPA seperti membuat tata tertib sekolah, menyediakan papan majalah dinding di setiap kelas, menyediakan berbagai peralatan kebersihan di setiap ruang kelas dan ruang lainnya, membuat slogan atau motto sekolah, menyediakan berbagai peralatan untuk beribadah, menyediakan alat komunikasi antara guru dengan orang tua peserta didik, men-setting lapangan upacara, menyediakan tempat ibadah, menyediakan kamar mandi dan air bersih, serta menyediakan kantin kejujuran.

d. Pemberian teladan kepada peserta didik oleh para guru. Karakter peserta didik sangat dipengaruhi oleh keteladanan guru. Guru meyakini jika perilakunya selalu diamati oleh peserta didik dan peserta didik akan meniru perilaku mereka. Itulah sebabnya para guru selalu berusaha untuk terbiasa menjadi teladan bagi peserta didiknya. Keteladanan tersebut juga menjadi salah satu prinsip bagi para guru dalam pembentukan karakter peserta didik. 
e. Komitmen guru terhadap visi sekolah. Pembentukan karakter peserta didik melalui PPA merupakan upaya untuk meraih visi sekolah untuk menghasilkan lulusan yang berkarakter. Itulah sebabnya komitmen guru terhadap visi sekolah sangat diperlukan agar mereka dapat bekerja dengan maksimal. Penguatan komitmen guru terhadap visi sekolah dilakukan pemberian motivasi bagi para guru oleh kepala sekolah, pengusulan pemberian reward kepada guru yang berprestasi kepada LPP/yayasan berupa kenaikan gaji, beasiswa S2, dan pemberian reward berupa ibadah haji dan umroh gratis bagi guru.

4. Melakukan perubahan organisasi sekolah untuk membentuk karakter peserta didik. Perubahan organisasi sekolah untuk membentuk karakter peserta didik di SD Al Irsyad Al Islamiyyah 02 Purwokerto dilakukan melalui empat upaya, yaitu:

a. Perubahan struktur organisasi sekolah. Perubahan struktur organisasi SD Al Irsyad Al Islamiyyah 2 Purwokerto dilakukan dalam rangka membentuk karakter peserta didiknya dilakukan melalui pendekatan desentralisasi. Pendekatan desentralisasi ini diterapkan atas dasar dan gagasan bahwa penciptaan satuan-satuan organisasi yang lebih kecil dan dapat berdiri sendiri akan meningkatkan motivasi para anggota satuan-satuan tersebut dan membantu mereka untuk memusatkan perhatiannya pada pelaksanaan berbagai kegiatan PPA yang sudah menjadi tugas dan tanggung jawabnya.

b. Desentralisasi kerja. Dalam organisasi sekolah yang sentralistik, kepala sekolah memegang kendali sepenuhnya terhadap penyelenggaraan pendidikan di suatu sekolah. Kepala sekolah tidak memberikan kewenangan kepada para guru untuk menyusun atau merencanakan program sekolah. Di sekolah, guru hanya berperan sebagai pelaksana. Sedangkan dalam organisasi sekolah yang berpola desentralisasi, kepala sekolah memberikan kewenangan kepada para guru untuk menyusun atau merencanakan program sekolah sekaligus melaksanakannya. Kepala sekolah berperan sebagai top leader yang mendukung, mengawasi dan mengevaluasi kinerja guru sebagai upaya perbaikan serta memfasilitasi para guru untuk saling bekerja sama.

c. Peningkatan produktivitas. Untuk meningkatkan produktivitas kerja pada tiap satuan kerja di SD Al Irsyad Al Islamiyyah 02 Purwokerto, kepala sekolah dan LPP/yayasan mengadakan halaqoh untuk meningkatkan kualitas keimanan dan ketaqwaan guru, mengadakan kursus-kursus seperti kursus bahasa Inggris, kursus bahasa Arab, kursus mendongeng, kursus quantum teaching, dan training camp untuk meningkatkan kompetensi guru. Sekolah dan 
LPP/yayasan juga mengirimkan guru yang berprestasi untuk studi lanjut S2 di STAIN Purwokerto, Unsoed (Universitas Soedirman), Universitas Muhammadiyah Purwokerto, Universitas Negeri Yogyakarta, dan Universitas Gajah Mada. Saat ini tercatat sebanyak 45 guru di yayasan Al Irsyad Al Islamiyyah Purwokerto sedang menempuh studi lanjut S2. Ilmu-ilmu dan berbagai keterampilan yang diperoleh guru baik melalui halaqoh, kursus-kursus, dan studi lanjut digunakan sebagai modal utama untuk melaksanakan program kegiatan PPA yang mereka susun.

d. Perbaikan karakter guru. Para guru menyadari bahwa untuk membentuk karakter peserta didik mereka harus berkarakter terlebih dahulu. Untuk mewujudkannya, sekolah difasilitasi oleh yayasan melaksanakan berbagai kegiatan seperti halaqah, mabit (malam bina iman dan taqwa), tahfidz juz 29 dan 30 serta suratsurat pendek, pengajian keagamaan, menghafal bacaan shalat beserta artinya, ikut melaksanakan shalat dhuhur berjama'ah bersama peserta didik, tidak merokok, istiqomah memakai jilbab, dan sebagainya. Berbagai kegiatan di atas diakui oleh kepala sekolah dan para guru memiliki kontribusi yang signifikan dalam membentuk karakter guru.

5. Menjalin kerjasama dengan wali peserta didik dalam membentuk karakter peserta didik. Bentuk kerjasama antara sekolah dengan wali peserta didik untuk membentuk karakter peserta didik di SD Al Irsyad Al Islamiyyah 02 Purwokerto dilakukan melalui upaya, yaitu:

a. Menyelenggarakan kegiatan parenting day. Kegiatan parenting day diselenggarakan oleh pihak sekolah dalam bentuk acara seminar dan pelatihan dengan tema-tema yang berhubungan dengan metode mendidik anak bagi para orang tua yang diikuti oleh seluruh wali peserta didik.

b. Mengadakan kegiatan halaqah bagi wali peserta didik. Kegiatan halaqah diadakan oleh pihak sekolah dalam bentuk tadarrus alQur'an dan pemberian mauidzah hasanah oleh guru al-Qur'an kepada wali peserta didik. Banyak wali peserta didik yang memanfaatkan kegiatan halaqoh ini untuk memperdalam kemampuan mereka dalam membaca al-Qur'an. Tidak sedikit orang tua yang merasa malu pada dirinya sendiri karena anakanaknya sudah lancar membaca al-Qur'an bahkan hafal Juz 'Amma dan juz 29 sementara mereka belum lancar membaca al-Qur'an.

c. Melaksanakan Program Call Center. Program call center sering dimanfaatkan oleh wali peserta didik untuk memberikan masukanmasukan kepada pihak sekolah terkait dengan penyelenggaraan pendidikan di sekolah, berkonsultasi dalam mendidik anak, dan sebagai sarana untuk berkomunikasi antara wali peserta didik dan 
wali kelas untuk mengetahui perkembangan karakter anak baik di rumah maupun di sekolah. Dalam program call center juga dilaksanakan kegiatan subuh call dan tahajud call. Dalam program tersebut wali kelas membangunkan wali peserta didik dengan menelponnya kemudian meminta kepada wali peserta didik untuk memerintahkan anaknya menunaikan shalat subuh dan shalat tahajud. Menurut para guru program tersebut juga ikut memotivasi wali peserta didik untuk melaksanakan shalat subuh dan shalat tahajud.

d. Menyelenggarakan kegiatan pengajian keagamaan. Berbagai kegiatan pengajian keagamaan diselenggarakan oleh pihak sekolah dengan diikuti oleh wali peserta didik bertepatan dengan hari besar keagamaan Islam, seperti isra mi'raj dan maulid nabi. Dalam pengajian itu pihak sekolah juga menyelinginya dengan berbagai pengumuman, seperti pengumuman program-program pada PPA.

e. Melaksanakan berbagai perlombaan untuk wali peserta didik. Berbagai kegiatan perlombaan yang pernah diselenggarakan seperti lomba memasak antar wali peserta didik. Selain digunakan untuk mempererat silaturahmi antara pihak sekolah dengan wali peserta didik dan antar wali peserta didik, perlombaan memasak ini oleh pihak sekolah juga dijadikan sebagai media untuk menguatkan komitmen wali peserta didik dalam membentuk karakter anakanaknya.

f. Melaksanakan kegiatan Home Visiting. Kegiatan home visiting atau kunjungan rumah dilaksanakan oleh wali kelas dan wali peserta didik. Kegiatan tersebut biasanya dilaksanakan secara terjadwal dan juga secara spontanitas ketika ada momen-momen tertentu, misalnya jika ada peserta didik yang sakit, jika ada wali peserta didik yang sakit, jika ada wali peserta didik yang mempunyai hajat, dan juga jika ada peserta didik yang bermasalah.

g. Memberikan lembar pantauan anak di rumah. Lembar pantauan anak di rumah merupakan instrumen yang digunakan untuk menilai sudah sejauh mana perkembangan karakter peserta didik, apakah sudah memenuhi standar mutu karakter atau belum. Sekolah memberikan kepercayaan sepenuhnya kepada wali peserta didik untuk mengisi lembar pantauan anak tersebut.

h. Membentuk komite sekolah tingkat unit. Komite sekolah di SD Al Irsyad Al Islamiyyah 02 Purwokerto dibagi menjadi dua, yaitu komite sekolah inti dan komite sekolah unit. Komite sekolah unit terdapat pada setiap level, jadi setidaknya ada 4 komite sekolah tingkat unit. Waka level melakukan kerjasama dengan komite sekolah tingkat unit di levelnya dalam menyelenggarakan kegiatan pendidikan, termasuk dalam penyelenggaraan PPA. Pembentukan 
komite sekolah tingkat unit tersebut ditujukan agar kerjasama antara pihak sekolah dengan komite sekolah bisa berlangsung secara efektif mengingat banyaknya jumlah wali peserta didik.

\section{SIMPULAN}

Implementasi TQM untuk membentuk karakter peserta didik melalui PPA di SD Al Irsyad Al Islamiyyah 02 Purwokerto merupakan sebuah inovasi pendidikan yang sangat gemilang dan faktual. Melalui upaya tersebut SD Al Irsyad Al Islamiyyah 02 Purwokerto telah ikut berperan serta dalam melaksanakan program pemerintah, yaitu pencanangan pelaksanaan program pendidikan karakter di sekolah-sekolah. Berdasarkan hasil penelitian dapat disimpulkan bahwa ada lima langkah yang dilakukan dalam implementasi TQM untuk membentuk karakter peserta didik di SD Al Irsyad Al Islamiyyah 02 Purwokerto. Pertama, melakukan perbaikan karakter peserta didik secara terus menerus (memfokuskan visi dan membuat program PPA). Kedua, menetapkan jaminan mutu karakter peserta didik. Ketiga, merubah budaya sekolah untuk membentuk karakter peserta didik (pembuatan dan penerapan tata tertib sekolah, pembiasaan, pengkondisian, pemberian teladan oleh guru, membangun komitmen guru tentang PPA). Keempat, melakukan perubahan organisasi sekolah untuk membentuk karakter peserta didik (mengubah struktur organisasi sekolah, melakukan desentralisasi kerja, meningkatkan produktivitas dan memperbaiki karakter guru). Kelima, menjalin kerjasama dengan wali peserta didik dalam membentuk karakter peserta didik (mengadakan parenting day, halaqah, call center, pengajian keagamaan, berbagai perlombaan untuk wali peserta didik, home visiting, memberikan lembar pantauan anak di rumah dan membentuk komite sekolah tingkat unit).

\section{DAFTAR PUSTAKA}

Afifudin dan Beni Ahmad Saebani. 2009. Metodelogi Penelitian Kualitatif. Bandung: Pustaka Setia.

Alwi, Hasan, dkk. 2002. Kamus Besar Bahasa Indonesia. Jakarta: Balai Pustaka. Arcaro, Jerome S. 2007. Pendidikan Berbasis Mutu: Prinsip-prinsip Perumusan dan Tata Langkah Penerapan. Terjemahan. Yosal Iriantara. Yogyakarta: 2007.

Arifin, Anwar. 2003. Memahami Paradigma Baru Pendidikan Nasional dalam UndangUndang Sisdiknas. Jakarta: Depag RI.

Asifudin, Ahmad Janan. 2010. Mengungkit Pilar-pilar Pendidikean Islam : Sebuah Tinjauan Filosofis. Yogyakarta: UIN Suka Press.

Bush, Tony dan Marianne Coleman. 2010. Manajemen Strategis Kepemimpinan Pendidikan. Terjemahan. Fahrurrozi. Yogyakarta: IRCiSoD.

Darwis, Amri. 2012. Redefinisi Pendidikan Agama Islam Dalam Terang Pendidikan Karakter. Media Pendidikan Jurnal Pendidikan Islam. Volume XXVII: Nomor 3. 
Gaspersz, Vincent. 2008. Total Quality Management. Jakarta: Gramedia Pustaka Utama.

Moloeng, Lexy J. 2011. Metodologi Penelitian Kualitatif. Bandung: Remaja Rosda Karya.

Novan Ardy Wiyani, Desain Budaya Islami di Sekolah Dasar, Jurnal Dialektika PGSD STKIP Islam Bumiayu, Vol. 2 No. 1 Jan-Apr 2012, hlm. 1-11.

Nurdin, Muslim, dkk. 2001. Moral dan Kognisi Islam: Buku Teks Agama Islam untuk Perguruan Tinggi Umum. Bandung: Alfabeta.

Patilima, Hamid. Metode Penelitian Kualitatif. Bandung: Alfabeta.

Sallis, Edward. 2010. Total Quality Management in Education. Terjemahan Ahmad Ali Riyadi dan Fahrurrozi. Yogyakarta: IRCiSoD.

Sulistyorini. 2009. Manajemen Pendidikan Islam : Konsep, Strategi, dan Aplikasi. Yogyakarta: Teras.

Syafaruddin dan Irwan Nasution. 2005. Manajemen Pembelajaran. Jakarta: Quantum Teaching.

Tahroni. 2009. Konfigurasi Pemikiran dalam Ilmu Pendidikan. Gorontalo: IPI Publishing.

Tjiptono, Fandy dan Anastasia Diana. 2009. Total Quality Management. Yogyakarta: Andi Offset.

Wiyani, Novan Ardy. 2012. Manajemen Pendidikan Karakter: Konsep dan Implementasinya di Sekolah. Yogyakarta: Pedagogia.

Zubaedi. 2012. Desain Pendidikan Karakter: Konsepsi dan Aplikasinya dalam Lembaga Pendidikan. Jakarta: Kencana. 